\title{
The Role of Fresh Graduates as Learning Volunteers in the Covid-19 Pandemic
}

\author{
Bertholomeus Jawa Bhaga ${ }^{1}$
}

DOI: 10.35445/alishlah.v13i1. 457

\begin{abstract}
Artucle Info Abstract
Keywords:

Learning Volunteers

Fresh Graduates

Covid-19 Pandemic

This study aim to knowing the effectiveness of efforts to empower the latest undergraduate graduates to help volunteer for learning during the Covid-19 pandemic. This research is qualitative research with a descriptive method that seeks to describe the role that the undergraduate can become a volunteer for learning. Data analysis techniques are in the form of collecting data from respondents. Data is reduced, data is presented, and then analyzed. The results obtained were found that fresh graduates were graduates who had just graduated from campuses around the Flores area in general and IKIP Muhammadiyah Maumere in particular and their roles in many ways teachers, students and being assistants. Parents in accompanying their children to study at and from home. From the implementation of this volunteer, it was found that there were changes in connection with the assisted learning process from home, which was enforced, school children felt helped in terms of progress in subject matter and were not left behind in understanding the material provided by teachers from school, parents and students also got new knowledge about the use of IT.
\end{abstract}

Kata kunci:

Relawan pembelajaran Sarjana fresh graduate Pandemi Covid-19

\begin{abstract}
Abstrak
Tujuan penelitian ini adalah untuk mengetahui keefektifan upaya memberdayakan sarjana lulusan terbaru dalam membantu menjadi relawan pembelajaran semasa pandemi covid-19. Penelitian ini adalah penelitian kualitatif dengan metode deskriptif yang berusaha mendeskripsikan peran yang dapat diampu oleh sarjana untuk menjadi relawan pembelajaran. Teknik analisis data berupa mengumpulan data dari responden, data direduksi, data disajikan lalu dianalisis. Hasil yang diperoleh ditemukan bahwa sarjana fresh graduate adalah para sarjana yang baru diwisuda oleh kampus-kampus sekitar daerah Flores pada umumnya dan IKIP Muhammadiyah Maumere pada khususnya dan peran mereka dalam banyak hal seperti menjadi pengajar relawan, menjadi pendamping IT bagi guru, peserta didik dan menjadi pendamping orang tua dalam mendampingi anak-anak belajar di dan dari rumah. Dari penerapan relawan ini ditemukan adanya perubahan sehubungan dengan terbantunya proses belajar dari rumah yang diberlakukan, anak-anak sekolah menjadi merasa terbantu dalam hal kemajuan materi pelajaran dan menjadi tidak tertinggal dalam menerima pelajaran yang diberikan oleh guru dari sekolah, orang tua dan siswa juga mendapatkan pengetahuan baru tentang penggunaan IT.
\end{abstract}

${ }^{1}$ IKIP Muhammadiyah Maumere, Flores, Indonesia

Email: berthojawa14@gmail.com 


\section{PENDAHULUAN}

Pendidikan adalah hal terpenting bagi setiap negara. Sebuah negara dikatakan hebat akan menempatkan pendidikan sebagai prioritas utama, karenanya, kemiskinan pada rakyat di negara tersebut akan dapat tergantikan menjadi kesejahteraan. Dalam perkembangannya, pendidikan di Indonesia senantiasa harus menghadapi beberapa masalah di setiap tahapnya. Semua masalah tentang pendidikan tersebut hanya dapat diselesaikan dengan partisipasi dari semua pihak yang terkait di dalam sistem pendidikan, seperti orang tua, guru, kepala sekolah, masyarakat, para sarjana lulusan baru dan juga peserta didik itu sendiri (Normina,2016). Partisipasi orang tua dan masyarakat akan tumbuh jika mereka juga merasakan manfaat dari keikutsertaannya dalam program sekolah. Manfaat dapat diartikan luas, rasa diperhatikan dan rasa puas karena dapat menyumbangkan kemampuannya bagi kepentingan sekolah. Pada prinsipnya membangun relasi dengan masyarakat adalah ketika semua pihak dapat saling memberikan kepuasan. Salah satu jalan penting untuk membina hubungan dengan masyarakat adalah menetapkan komunikasi yang efektif. Orang tua juga memiliki peranan besar untuk mengenalkan nilai-nilai baik kepada anak-anak mereka. Orang tuapun bertanggung jawab penuh untuk mendidik anak-anak mereka dengan nilainilai kepemimpinan, sehingga mereka mempunyai modal yang mumpuni untuk menjadi pemimpin ketika mereka mulai memasuki lembaga formal atau dunia kerja, seperti sekolah. Yang lebih luar biasa adalah bahwa pendidikan mampu menumnuhkan kembali kerja sama yang intim, efektif dan efisien antara orang tua dan guru.

Selama masa pandemi ini, peserta didik tentunya akan menghabiskan waktu belajar di rumah. Di mana ini menuntut adanya kolaborasi yang inovatif antara orang tua dan guru sehingga peserta didik tetap dapat menjalani belajar online dengan efektif. Selain itu, kolaborasi yang inovatif ini juga dapat mengatasi berbagai keluhan selama menjalani belajar dari rumah. Ini akan memberikan dampak positif bagi dunia pendidikan baik di masa kini maupun masa mendatang (Wahyu, 2020). Selain itu, kolaborasi yang apik antara orang tua, para guru dan kepala sekolah untuk memberikan dukungan kepada peserta didik dalam menerapkan nilai-nilai kepempinan yang baik melalui budaya organisasi di sekolah. Terakhir, peserta didik harus menemui begitu banyak tantangan di luar sekolah. Dari beberapa permasalahan yang timbul pada tiap tahapan itu, sekarang muncul persoalan baru yakni kesempatan belajar yang aman dan nyaman menghadapi pandemi covid -19 .

Warga Indonesia pada khususnya sedang berada pada masa-masa sulit. Masa sulit ini disebabkan oleh hadirnya pandemi yang tidak berujung. Pandemi telah mendatangkan banyak efek ikutan pada berbagai sisi kehidupan, salah satunya adalah soal pendidikan. Ketika pemerintah mencari solusi untuk penanganan masalah belajar mengajar siswa kita, juga saat yang bersamaan timbul masalah-masalah ikutan juga seperti permasalahan guru dan siswa berupa lemahnya sumber daya manusia dalam penguasaan IT dan terbatasnya akses pengawasan terhadap siswa, dari siswa berupa kurangnya aktivitas dalam pembelajaran, terbatasnya fasilitas penunjang dan akses jaringan internet, sedangkan dari orang tua berupa waktu terbatas untuk menemani anak-anak mereka selama pembelajaran online. Berbagai permasalahan tersebut dapat diatasi dengan peningkatan kompetensi penguasaan TI, pengawasan intensif dengan melibatkan peran orang tua, dan pemberian tugas manual (Putra, 2020).

Untuk menyiasati agar anak-anak sekolah tidak terlambat dalam hal pencapaian target perolehan materi pelajaran, maka pemerintah mulai memikirkan berbagai cara untuk itu, salah satu adalah dengan pemberlakuan pembelajaran dalam jaringan atau biasa disingkat daring. Daring ini pada awal mulanya diyakini sebagai langkah bagi guru dan peserta didik agar proses belajar mengajar dapat terus dilaksanakan. Namun, seiring dengan pemberlakuan itu sendiri, ternyata daring malah mendatangkan banyak efek ikutan berupa masalah baru seperti yang telah disebutkan terdahulu misalnya permasalahan guru dan siswa berupa lemahnya sumber daya manusia dalam penguasaan IT dan terbatasnya akses pengawasan terhadap siswa, dari siswa berupa kurangnya 
aktivitas dalam pembelajaran, terbatasnya fasilitas penunjang dan akses jaringan internet, sedangkan dari orang tua berupa waktu terbatas untuk menemani anak-anak mereka selama pembelajaran online.

Pendidikan harus tetap berjalan, pandemi ini telah menjadi tantangan tersendiri bagi setiap sekolah di semua negara, metode kegiatan belajar mengajar disekolah (KBM) yang selama ini berlangsung harus dibenah dan dapat menyesuaikan diri dengan situasi saat ini dan senantiasa memperhatikan protokol kesehatan yang ada agar dalam proses kegiatan belajar mengajar disekolah (KBM) dapat memberikan rasa aman dan melindungi sisiwa dan siswi serta tenaga pendidik dari bahaya penularan Covid-19.

Indonesia sebagai salah satu negra terdampak akhirnya menerapkan kebijakan new normal. Suatu kebijakan yang telah dilaksanakan dengan mempertimbangkan segala sesuatunya. Kebiasaan ini telah diterapkan di sebagai daerah-daerah yang masuk kategori dapat meminalisir dan dapat mengontrol laju perkembangan Covid-19. Kebijakan pemberlakuan new normal ini juga bukan hanya saja diperuntukkan untuk sektor ekonomi, sektor transportasi, namun juga sektor pendidikan.

Relawan pendidikan selama masa pandemi ini adalah orang-orang yang dengan kemauan yang besar dan niat yang tulus untuk membantu keberlangsungan pendidikan untuk semua warga bangsa. Maka, untuk menjadi relawan ini semua sarjana fresh graduate dapat terlibat di dalamnya atau dapat diberdayakan. Tentang relawan di bidang pendidikan ini, ada beberapa contoh yang pernah terjadi misalnya Peran komunitas Sokola Kaki Langit mendidik para peserta didik di Bonto Manai Kabupaten Maros yang meliputi: (a) Membentuk kelas yang bernama kelas nonformal. (b) Memberikan bantuan pada pihak sekolah dalam pembelajaran formal. (c) membentuk rumah baca/perpustakaan. (d) memberikan edukasi tentang pentingnya pendidikan. (e) Kolaborasi aktif dengan pihak keluarga murid binaan. (f) membangun kolaborasi dengan pihak sekolah. (g) Berkolaborasi dengan masyarakat (Asrianto : 2018). Sedangkan, sehubungan dengan pemberdayaan para sarjana lulusan terbaru, konsep ini diyakini sekiranya dapat membantu mengatasi tantangan pembelajaran di masa pandemi. Tiap sarjana dengan berbagai keahlian yang dimilikinya dapat membantu sesama warga sekitar untuk memperlancar kegiatan belajar bagi siswasiswi baik tingkat TK, SD, SMP maupun SMA. Para relawan dapat membantu mendampingi para peserta didik sesuai dengan tingkatannya. Misalnya soal baca, tulis dan hitung (tingkat SD), dan berbagai konsep dan materi untuk tingkat SMP dan SMA/SMK yang disesuaikan pula dengan basic keilmuan pada relawan.

Menurut Syah (2020) pembelajaran daring yang dilaksanakan selama ini mempunyai berbagai kekurangan diantaranya adalah minimnya pengetahuan yang berhubungan dengan teknologi informasi oleh guru dan siswa, ketersediaan sarana dan prasarana yang tidak memadai, kesempatan akses internet yang susah dan terbatas, kurangnya penyediaan anggaran atau biaya yang digunakan untuk pembelajaran daring ini. Selain itu, pembelajaran daring juga menuntut orang tua untuk selalu mendampingi anaknya selama belajar dari rumah. Pendapat ini jelas menggambarkana konsisi riil yang sedang terjadi di Indonesia. Inilah kesenjangan di satu sisi keberlangsungan pendidikan warga negara harus tetap berjalan namun di sisi lain ternyata masih terdapat banyak kendala yang dihadapi sehubungan dengan ketersediaan sarana prasarana pendukung dan sumber daya manusia itu sendiri.

Selain mendampingi para peserta didik memahami berbagai konsep dan materi sesuai dengan tingkat dan jenjangnya, relawan bidang pendidikan juga dapat berperan sebagai pioner atau pendamping dalam menggunakan teknologi bagi peserta didik itu sendiri, para guru dan orang tua dalam melaksanakan pembelajaran daring. Alasan pertama adalah keterbatasan penguasaan teknologi informasi oleh guru dan siswa. Kondisi guru di Indonesia dapat dikatakan tidak seluruhnya memahami dalam artian dapat mengoperasikan peralatan teknologi, hal ini bisa diamati dari guru-guru generasi tahun sebelum 1980-an. Kendala teknologi informasi inilah yang menjadi penghalang atau hambatan tersendiri bagi guru-guru tersebut dalam menggunakan media untuk 
belajar daring. Di sisi lain juga dengan siswa yang kondisinya hampir sama dengan guru-guru yang dimaksud dengan pemahaman penggunaan teknologi tersebut (Pujilestari, 2020) . Dengan alasan demikian maka dapat memberdayakan para relawan untuk turut membantu mengatasi kendala ini.

Tujuan adanya pemberdayaan relawan ini adalah untuk memfasilitasi hal penggunaan teknologi informasi bagi peserta didik di lingkungan sekitar juga dalam hal belajar, terutama dalam memahami mata pelajaran yang sulit selama pembelajaran daring dari sekolah. Metode pelaksanaan ini ditujukan untuk membantu meringkankan keterbatasan masyarakat dalam menghadapi efek pandemi Covid-19. Selain itu, program ini dilakukan sebagai wujud penilaian keefektifitasan dari proses pembelajaran dengan bantuan para relawan sarjana fresh graduate untuk meningkatkan prestasi siswa, mengingat sulitnya proses belajar mengajar dengan bantuan orang tua di era daring karena Covid-19. Menjadi relawan pembelajaran di rumah ini dilatarbelakangi oleh adanya permasalahan pada situasi pandemi, di mana hampir seluruh sekolah ditutup dan para siswa dinyatakan belajar di rumah, serta kurang bervariasinya metode dan media pembelajaran oleh para orang tua di rumah, sehingga berdampak pada kurangnya minat belajar para siswa. Sibuknya para orang tua juga mempengaruhi kualitas kegiatan belajar para siswa di rumah. Dengan kehadiran relawan ini kiranya dapat memmbuat siswa menjadi lebih aktif dalam belajar. Keaktifan belajar ditandai oleh adanya perpaduan atau kolaborasi apik, dari aspek intelektual, emosional, dan fisik jika dibutuhkan (Aunurrahman, Gunawan, dkk, Pendampingan Penerapan Strategi Pembelajaran Inovatif (43 2012). Dengan kata lain, siswa dikatakan aktif apabila semua sumber daya tercurah untuk mencapai satu tujuan yang sama, dengan menggerakan semua sumber daya yang dimiliki pada siswa itu.

Aktivitas belajar dikategorikan ke dalam empat hal , yakni: (1) visual activity, yakni membaca, memperhatikan, mengamati, demonstrasi, dan sebagainya; (2) oral activity, yakni mendengar, menerima, diskusi, dan sebaginya; (3) drawing activity, yakni menggambar, membuat grafik, membuat peta, diagram dan sebagainya; dan (4) writing activity, yakni menulis cerita, membuat rangkuman, menulis laporan, dan sebagainya (Hamalik : 2004).

Sejauh ini telah ada beberapa penelitian yang dilakukan untuk melihat bagaimana pembelajaran daring dilakukan di masa pandemi COVID-19. Penelitian oleh Luh Devy Herliandry et al (2020), Sulata \& Hakim (2020), Wahyu Aji Fatma Dewi (2020), Ali Sadikin \& Afreni Hamidah (2020), Damayanthi (2020 ) menunjukkan bahwa untuk keadaan darurat selama masa pandemi COVID 19, di mana pembelajaran daring menjadi pilihan yang harus diambil oleh perguruan tinggi untuk memastikan proses pembelajaran tetap berlangsung, dinilai dapat menggantikan pembelajaran konvensional secara tatap muka. Namun dengan penerapan pembelajaran daring yang dilakukan secara mendadak dan tanpa persiapan, tujuan pembelajaran belum dapat tercapai. Penyediaan sarana teknologi informasi yang mendukung pembelajaran daring, kemampuan siswa, guru dan orang tua untuk menggunakan teknologi untuk mendukung proses pembelajaran, dan kondisi jaringan internet yang stabil sangat berpengaruh terhadap keberhasilan pembelajaran daring guna mencapai tujuan pembelajaran.

Penelitian tentang relawan pembelajaran di masa pandemi juga dilakukan oleh Suprihatin, dkk (2020). Adapun beberapa strategi yang digunakan oleh mahasiswa dalam proses pendampingan belajar, antara lain (1) tatap muka (ceramah) dalam kelompok yang terbatas dengan tetap mematuhi protokoler kesehatan yang ketat, (2) Tanya-jawab, (3) Kuis, (4) Ice breaking, (5) Latihan Kreativitas, (6) Bimbingan daring. Hasil yang diperoleh diketahui bahwa beberapa kegiatan tersebut dinilai efektif membantu para siswa selama masa pandemi dalam hal belajar di rumah.

Dari beberapa penelitian yang telah dilakukan sebelumnya, terdapat beberapa kesamaan yakni objek yang diteliti adalah siswa selama masa pandemi. Ada pun beberapa hal yang menjadi perbedaan dengan penelitian yang sedang dilakukan adalah penelitian ini berupaya mengukur sejauh mana efektifitas memberdayakan sarjana lulusan terbaru menjadi relawan pembelajaran dengan menjadi pengajar sekaligus menjadi pendamping IT bagi orang tua dan siswa yang sedang 
belajar, sedangkan penelitian sebelumnya sebagian besar fokus pada siswa dan mahasiswa yang sedang menempuh pendidikan di perguruan tinggi.

\section{METODE}

Fokus penelitian adalah pemberdayaan para sarjana lulusan terbaru untuk menjadi relawan pembelajaran dalam masa pandemi covid-19. Untuk memperoleh dan mengumpulkan data, peneliti menggunakan metode kualitatif dan jenis penelitian deskriptif. Lokasi penelitian ini bertempat di 8 desa yang tersebar di Kecamatan Kewapante, Kabupaten Sikka Propinsi Nusa Tenggara Timur. Data penelitian ini didapatkan melalui sumber primer dan sumber sekunder. Data primer adalah data yang diperoleh langsung di lokasi penelitian, melalui pengamatan langsung di lapangan dan melalui proses wawancara dengan informan. Sedangkan data sekunder adalah data yang diperoleh dari studi literatur. Berkaitan dengan sumber data yang akan digunakan dalam penelitian ini, sumber data dapat berupa manusia sebagai informan, hasil wawancara, atau sumber tertulis yang mendukung untuk dijadikan data dalam penelitian ini seperti artikel, majalah, berita, ataupun koran. Informan pendukung dalam penelitian ini adalah orang tua peserta didik, guru baik SMP maupun SMA serta para pemangku kebijakan seperti camat dan kepala desa. Informan pendukung berperan sebagai informan yang dapat memberikan arahan untuk menemukan informasi kunci. Setelah mendapatkan data dari informan pendukung, peneliti melakukan wawancara kepada informan kunci guna melengkapi dan mencari jawaban atas topik pembahasan penelitian. Informan kunci penelitian ini adalah para guru, orang tua dan para siswa. Lama waktu penelitian ini adalah bulan sejak tanggal 10 Desember 2020 sampai dengan tanggal 10 Januari 2021. Data dalam penelitian ini dikumpulkan melalui hasil oleh angket dari responden, setelah data dikumpulkan lalu diklasifikasikan tentang persepsi responden tentang efektifitas relawan di lapangan, peran relawan dalam beberapa kegiatan baik sebagai pengajar pada kelas terbatas maupun sebagai pendamping IT bagi siswa, orang tua dan guru. Setelah

\section{HASIL PENELITIAN DAN PEMBAHASAN}

Berdasarkan angket yang telah disebarkan kepada responden ditemukan beragam respon sebagai jawaban sementara atas tujuan penelitian ini yakni mengukur sejauh mana relawan pembelajaran diberdayakan. Responden penelitian ini berjumlah 75 orang yang terdiri dari orang tua wali murid (68\%) dan guru (32\%) yang berada di Kecamatan Kewapante, Kabupaten Sikka NTT. Desa/kelurahan tempat tinggal responden yaitu di daerah Geliting (9,3\%), Namangkewa (34,6\%), Ian Tena (9,3\%), Kopong (10,6\%), Seusina (10,6\%), Umagera (6,6\%), Waiara (10,6\%), dan Wairkoja (8\%).

\section{Menjadi Pengajar}

Menyikapi situasi pembelajaran yang tidak berjalan dengan efektif akibat pandemi, maka para sarjana fresh graduate secara langsung terjun menjadi relawan pengajar di masing- masing desanya. Relawan menjadi pengajar di sekolah-sekolah yang dapat dijangkau dari tempat tinggal mereka. Relawan penelitian ini berjumlah 98 orang yang terdiri dari beberapa keahlian atau latar belakang pendidikan yakni : Pendidikan Bahasa dan Sastra Indonesia 22 orang, Pendidikan Bahasa Inggris 10 orang, Pendidikan Pancasila dan Kewarganegaraan 15 orang, Pendidikan Ekonomi 8 orang, Pendidikan Matematika 8 orang, Pendidikan Fisika 10 orang, Pendidikan Biologi 10 orang, dan Pendidikan Kimia 15 orang.

Dari angket yang disebar diketahui bahwa responden setuju jika relawan telah mampu menyiapkan materi pembelajaran dengan baik $(61,3 \%) .26,7 \%$ responden sangat setuju jika relawan telah menyiapkan dengan baik. Hal ini tentu sebelum menjadi relawan, mereka telah melakukan beberapa hal yakni:

a. Melakukan koordinasi dengan pihak sekolah di sekitar tempat tinggal sarjana fresh graduate. 
b. Setelah mengetahui sebaran siswa yang ada, maka pihak sekolah (guru) dapat memberikan gambaran perkembangan cakupan materi yang telah diajarkan sebelumnya.

c. Selain memberikan gambaran tentang materi, guru dan relawan dapat saling berkoordinasi tentang berbagai sumber belajar, buku rujukan atau buku pelajaran yang dipakai agar memudahkan relawan menjalani pendampingan nantinya.

d. Relawan mengetahui jumlah dan sebaran peserta didik di sekitar tempat tinggalnya.

e. Melalui guru, semua perserta didik dibangun komunikasi untuk memastikan akan ada relawan yang mendampingi.

f. Relawan bersama guru bersepakat saat yang tepat untuk dapat mengunjungi peserta didik

g. Relawan mulai aksi di lapangan yang sesuai dengan latar belakang keilmuan yang dimiliki. Kondisi ini akan menjadi baik jika terdapat banyak relawan dari berbagai basic keilmuan.

Selain itu, ada $48 \%$ responden yang terdiri dan orang tua wali murid dan guru yang setuju relawan telah mempersiapkan materi dengan baik. Hal ini tentu disebabkan karena sebelum turun menjadi relawan sebelumnya melakukan koordinasi yang baik dengan guru atau pihak sekolah yang tersebar di dalam kecamatan Kewapante baik SMP maupun SMA/SMK dan hanya sekitar 5.3\% yang tidak setuju jika relawan pembelajaran telah menyiapkan materi dengan baik. Fakta lain juga menyatakan bahwa 66,7\% responden sangat setuju bahwa siswa sangat memahami materi yag diajarkan oleh relawan. Hal menyangkut relasi antara relawan dan siswa selama masa pandemi ini menunjukkan hal positif yakni sebanyak 69,3\% responden meyatakan siswa tidak canggung dengan relawan pembelajaran. Ini tentu membawa hal baik jika kehadiran relawan sangat membantu kesulitan belajaran yang dialami oleh siswa ,orang tua maupun guru nyang ada di Kecamatan Kewapante, Kabupaten Sikka, Nusa Tenggara Timur. Indikator lainnya adalah, siswa dapat berkomunikasi dengan baik. Data terlihat bahwa 65,3\% sangat setuju siswa berkomunikasi dengan baik dengan relawan dalam proses belajar bersama.

\section{Menjadi pendamping IT peserta didik dan orang tua}

Relawan pembelajaran yang adalah sarjana fresh graduate juga dapat menjadi pendamping IT bagi anak-anak yang sedang belajar dari rumah. Ada berbagai macam kemudahan yang dapat diperoleh jika hal ini dilaksanakan dan memiliki nilai positif misalnya :

a. Adanya kontrol yang baik bagi peserta didik sepanjang pembelajaran daring, peserta didik konsentrasi menggunakan android maupun laptop untuk pembelajaran dan tidak untuk hal-hal yang negatif ( membuka film atau game online).

b. Untuk orang tua yang tidak dapat mendampingi peserta didik belajar, maka dengan cara ini menjadi sangat terbantu dalam pembelajaran daring bagi peserta didik.

c. Saat yang bersamaan akan adanya pengalaman baru yang didapatkan dari relawan oleh peserta didik tentang cara mengoperasikan android dan komputer (bagi peserta didik yang belum mahir).

Ada beberapa poin yang menunjukkan bahwa kehadiran relawan pembelajaran yang merupakan para lulusan terbaru membawa dampak positif bagi siswa dan orang tua. Sebanyak 45,3 $\%$ responden menyatakan sangat setuju relawan mendampingi dengan baik menyangkut IT kepada siswa dan hanya $4 \%$ yang menyatakan tidak setuju akan hal ini. Ada sekitar $64 \%$ setuju bahwa siswa menjadi lebih efektif dan efisien mengunakan IT setelah adanya pendampingan oleh relawan. Hal ini sejalan dengan penelitian oleh Dewi (2020) yang menyatakan bahwa dampak COVID-19 terhadap proses pembelajaran online di sekolah dasar berdampak terhadap siswa, orang tua dan guru itu sendiri. Beberapa dampak yang dirasakan siswa yaitu karena belum adanya kebiasaan yang pernah dirasakan oleh para peserta didik untuk belajar dari jarak jauh, artinya guru berada 
pada tempat yang berbeda dengan peserta didik, pembelajaran hanya dilaksanakan menggunakan media belajar baik berupa buku modul atau media komunikasi. Peserta didik sudah terbiasa dengan sistem guru bertatap muka langsung dengan peserta didik secara langsung. Dengan adanya kebiasaan baru ini, harus dilalui dengan adanya pembiasaan sebelumnya, dilatih secara terus menerus agar menjadi hal yang biasa bagi perserta didik. Sedangkan bagi orang tua juga mendatangkan dampak secara ekonomi, bahwa pembelian kuota menjadi beban baru dalam list kebutuhan yang harus dipenuhi. Selain itu, guru-guru juga merasakan adanya dampak dengan adanya belajar daring ini yakni keharusan untuk menguasai teknologi informasi oleh semua guru tanpa memandang guru senior maupu junior. Dewi (2020), menemukan fenomena yang dialami oleh seorang guru yang membuka kelas dari pukul 07.00 hingga 12.00. Dalam hal pelaksanaan belajar di rumah guru meminta bantuan orang tua atau kakak siswa sebagai narasumber yang langkah-langkahnya telah diberikan melalui grup whatsapp. Untuk laporan pelaksanaan pembelajaran dapat berupa foto atau video yang harus diposting melalui grup.

Beberapa metode pembelajaran secara daring yang telah diterapkan yaitu pembelajaran melalui portal rumah belajar dan penyampaian materi melalui file word yang dibagikan melalui media sosial whatsapp (Pengelola Web Kemendikbud, 2020). Pembelajaran daring saat ini dijadikan solusi dalam masa pandemi COVID-19. Tetapi pembelajaran daring tidak mudah seperti yang dibayangkan. Salah satu tenaga pendidik disalah satu sekolah dasar mengatakan dalam pembelajaran dia menggunakan zoom untuk meeting (pertemuan) tatap muka selayaknya di kelas. Tetapi tidak semua anak bisa akses karena ada yang orang tuanya masih kerja, ada juga orang tua yang gagap teknologi

Orang tua siswa menyatakan sangat setuju jika kehadiran relawan membantu orang tua untuk belajar IT. Dengan itu, jika orang tua berhadapan pada situasi sulit maka mereka telah memiliki pengetahuan penggunaan IT untuk mendampingi anak-anak mereka saat menyelesaikan berbagai tugas dari sekolah. Pada kasus-kasus tertentu, ada orang tua yang menyediakan android dan komputer tetapi belum memiliki keterampilan untuk mengoperasikannya. Maka dengan kehadiran relawan para sarjana fresh graduate diharapkan dapat mendampingi orang tua peserta didik untuk belajar mengopersikan berbagai peralatan seperti android maupun komputer. Ini bertujuan agar orang tua segera mungkin memiliki keterampilan akan hal ini sehingga kelak jika berhadapan dengan situasi tertentu misalnya tanpa relawan maka akan dengan mudah mereka dapat mengoperasikan komputer dan android untuk membantu menyelesaikan berbagai tagihan belajar anak berupa pekerjaan rumah ataupun mencari berbagai sumber/ referensi yang berkaitan dengan materi yang sedang dipelajari oleh anak-anak mereka. Dan yang terkahir, ada sebanyak 52\% responden yang sangat setuju jika siswa dan orang tua sangat maksimal belajar IT bersama relawan.

\section{SIMPULAN}

Proses belajar anak selama pandemi di rumah menuai banyak kesenjangan. Orang tua yang tidak memiliki waktu serta kemauan mendampingi peserta didik menjadi pemicu ketertinggalan anak memahami materi tertentu. Untuk itu dengan kehadiran relawan sarjana fresh graduate dinilai tepat untuk mendampingi orang tua dalam mendidik anak-anak mereka. Peran para relawan disini adalah memberikan pemahaman serta pengetahuan dasar dalam mendidik, bersama orang tua mencermati berbagai materi yang diberikan oleh guru dari sekolah, membantu memecahkan persoalan sehubungan dengan kebingungan yang terjadi selama orang tua mendampingi anak-anak mereka dan menjadi pendamping IT bagi siswa dan orang tua. Hasilnya dapat disimpulkan relawan sangat efektif diberdayakan selama masa pandemi covid-19 dalam hal membantu ketertinggalan pembelajaran pada siswa di rumah masing-masing.

Dari penelitian ini dapat berimpilikasi bagi ilmu pengetahuan yakni menerapkan relawan untuk menjadi pengajar di masa pandemi, karena selain membantu para siswa dapat tetap belajar dari rumah, orang tua dan siswa itu pula dapat dibimbing sehubungan dengan penguasaan dan penggunaan IT. Bagi para pemangku kebijakan dapat juga menjadi dasar pemikiran dalam 
mengambil langkah yang tepat untuk menghadapi berbagai situasi ke depan sehubungan dengan pembelajaran di sekolah-sekolah.

\section{DAFTAR PUSTAKA}

Asrianto. (2018). Peran Komunitas Sokola Kaki Langit Dalam Membina Anak Usia Sekolah Di Bonto Manai Kabupaten Maros. Pendidikan Sosiologi FIS-UNM

Aunurrahman. (2012). Belajar dan Pembelajaran. Bandung: Alfabeta

Ayi, Suprihatin, Dkk. (2020). Efektivitas Pendampingan Belajar Anak Dalam Mengatasi Kesulitan Orang Tua Saat Pembelajaran Daring Di Masa Pandemi di Desa Kebulusan, Kabupaten Kebumen. Universitas Negeri Semarang, Semarang, Indonesia

Damayanthi, Adriana. (2020). Efektivitas Pembelajaran Daring Di Masa Pandemi Covid-19 pada Perguruan Tinggi Keagamaan Katolik. Jurnal Edutech, 8(2).

Dewi, Wahyu Aji Fatma. (2020). Dampak Covid-19 Terhadap Implementasi Pembelajaran Daring Di Sekolah Dasar. Edukatif : Jurnal Ilmu Pendidikan, 2 (1). 55-61 .

Firman, F., \& Rahayu, S. (2020). Pembelajaran Online di Tengah Pandemi COVID-19. Indonesian Journal of Educational Science (IJES), 2(2), 81-89. https:// doi.org/10.31605/ijes.v2i2.659

Ginandjar Kartasasmitha. (1996). Pembangunan Untuk Rakyat: Memadukan Pertumbuhan dan Pemerataan. Jakarta: PT Pusaka Cisendo

Hamalik, Oemar . (2004). Psikologi Belajar dan Mengajar. Bandung: Sinar Baru Algensindo.

Isbandi. (2008). Intervensi Komunitas Pengembangan Masyarakat Sebagai Upaya Pemberdayaan Masyarakat. Jakarta : PT Grafindo Persada

KBBI Daring. (2020). Efektif [daring] Dapat diakses di: https://kbbi.kemdikbud.go.id/

Munawar Noor. (2011). Pemberdayaan Masyarakat. Jurnal Ilmiah CIVIS, 1(2). 34-46.

Mustakim. (2020). Efektivitas Pembelajaran Daring Menggunakan Media Online Selama Pandemi COVID-19 Pada MataPelajaran Matematika the Effectiveness of ELearning Using Online Media During the COVID19 Pandemic in Mathematics. Al Asma: Journal of Islamic Education, 2(1), 1-12.

Nakayama M, Yamamoto H, \& S. R. (2007). The Impact of Learner Characterics on Learning Performance in Hybrid Courses among Japanese Students. Elektronic Journal ELearning. Vol.5(3): 22-41

Normina. (2016). Partisipasi Masyarakat Dalam Pendidikan. Ittihad Jurnal. 14 (2).

Pujilestari, Y. (2020). Dampak positif pembelajaran online dalam sistem pendidikan Indonesia pasca pandemi covid-19. Buletin Hukum dan Keadilan, 4(1): 49-56.

Putra, Made Waisnawa. (2020). Kompleksitas Permasalahan Pada Penerapan Pembelajaran Jarak Jauh (Pjj Moda Daring) Di Era Covid 19 (Faktor Penguasaan Guru, Siswa, Orang Tua) "Solusi \& Pemecahan Masalah" (Studi Kasus Di SMP Paramarta Semester Ganjil Ta 2020/2021). Cetta : Jurnal Ilmu Pendidikan. 4(1): 23-34

Ramadhan, Rizky, Uwes Anis Chaeruman, dan Cecep Kustadi. (2020). Pengembangan Pembelajaran Bauran (Blended Learning) di Universitas Negeri Jakarta. Jurnal Pembelajaran Inovatif. Vol 1(1) : 37-48

Sadikin, Ali, dan Afreni Hamidah. (2020). Pembelajaran Daring di Tengah Wabah Covid19. BIODIK: Jurnal Ilmiah Pendidikan Biologi, Vol 6(2) : 214-224

Syah, R. H. (2020). Dampak Covid-19 pada Pendidikan di Indonesia: Sekolah, Keterampilan, dan Proses Pembelajaran. SALAM: Jurnal Sosial dan Budaya Syar-i, 7(5).

Singh, G., 'donoghue, J. O., \& Worton, H. (2005). A Study Into The Effects Of eLearning On Higher Education. Journal of University Teaching \& Learning Practice , 2(1)

Wahyu Aji Fatma Dewi (2020). Dampak Covid-19 terhadap implementasi pembelajaran daring di Sekolah Dasar. Jurnal Ilmu Pendidikan. 2 (1) : 55-61

World Health Organization. Pertanyaan dan Jawaban Terkait Coronavirus [daring] Dapat diakses di: https://www.who.int/indonesia/news/novel-coronavirus/qa-for-public

Zhafira, Nabila Hilmi, Yenny Ertika, dan Chairiyaton. (2020). Presepsi Mahasiswa Terhadap Perkuliahan Daring Sebagai Sarana Pembelajaran Selama Masa Karantina Covid-19. Jurnal Bisnis dan Kajian Strategi Manajemen, Vol 4(1) : 37-45 